IZA DP No. 5647

Decentralization, Happiness and the Perception of Institutions

Luis Diaz-Serrano

Andrés Rodríguez-Pose

April 2011 


\title{
Decentralization, Happiness and the Perception of Institutions
}

\author{
Luis Diaz-Serrano \\ Universitat Rovira i Virgili, \\ CREIP and IZA
}

\author{
Andrés Rodríguez-Pose \\ London School of Economics \\ and IMDEA Social Sciences
}

\section{Discussion Paper No. 5647 \\ April 2011}

\section{IZA}

P.O. Box 7240

53072 Bonn

Germany

Phone: +49-228-3894-0

Fax: +49-228-3894-180

E-mail: iza@iza.org

\begin{abstract}
Any opinions expressed here are those of the author(s) and not those of IZA. Research published in this series may include views on policy, but the institute itself takes no institutional policy positions.

The Institute for the Study of Labor (IZA) in Bonn is a local and virtual international research center and a place of communication between science, politics and business. IZA is an independent nonprofit organization supported by Deutsche Post Foundation. The center is associated with the University of Bonn and offers a stimulating research environment through its international network, workshops and conferences, data service, project support, research visits and doctoral program. IZA engages in (i) original and internationally competitive research in all fields of labor economics, (ii) development of policy concepts, and (iii) dissemination of research results and concepts to the interested public.
\end{abstract}

IZA Discussion Papers often represent preliminary work and are circulated to encourage discussion. Citation of such a paper should account for its provisional character. A revised version may be available directly from the author. 
IZA Discussion Paper No. 5647

April 2011

\section{ABSTRACT}

\section{Decentralization, Happiness and the Perception of Institutions ${ }^{*}$}

This paper analyses whether the different powers and resources at the disposal of local and regional governments across Europe deliver greater satisfaction with political institutions and lead to greater personal happiness. The analysis uses microdata from the four available waves of the European social survey (2002, 2004, 2006 and 2008), including more than 160,000 observations of individuals living in 29 European countries. Our results reveal that political and fiscal decentralization have a positive and significant effect on individuals' overall happiness. Fiscal decentralization also exerts a significant effect on the level of satisfaction with political and economic institutions and with the education and health systems, whereas the effect of political decentralization on these variables is more limited. The results show that citizens seem to be happier with the actual capacity of their local governments to deliver than with the general principle that they can have a say on their daily politics and policies.

JEL Classification: $\quad \mathrm{H} 11, \mathrm{H} 77$

Keywords: happiness, well-being, satisfaction, fiscal and political decentralization, Europe

Corresponding author:

Luis Diaz-Serrano

Departament d'Economia

Universitat Rovira i Virgili

Av. de la Universitat 1

43204 Reus

Spain

E-mail: luis.diaz@urv.cat

\footnotetext{
* Luis Diaz-Serrano acknowledges the financial support from the Spanish Ministry of Science and Innovation (grant \# ECO2010-20829). Andrés Rodríguez-Pose is grateful for the support of the European Research Council under the European Union's Seventh Framework Programme (FP7/20072013) / ERC grant agreement $n^{\circ} 269868$ and of a Leverhulme Trust Major Research Fellowship. The research is also part of the Prociudad-CM programme and of the UK Spatial Economics Research Centre. The usual disclaimer applies.
} 


\section{Introduction}

The potential implications of processes of decentralization, devolution, and/or federalism have attracted considerable academic and political attention. This is no surprise in a world which has experienced a significant drive towards decentralization in recent decades and where people living in countries with a higher or lower degree of political or fiscal decentralization now clearly outnumber those living in centralised countries.

Most of this interest has been centred on the economic implications of the transfers of powers and resources to subnational tiers of government. Macroeconomic studies have predominated. Whether decentralization has led to greater economic efficiency (Davoodi and Zou, 1998; Thießen, 2003; Rodríguez-Pose and Bwire, 2004; Iimi, 2005; Rodríguez-Pose and Ezcurra, 2011) or resulted in greater or lower territorial inequality (Gil Canaleta et al., 2004; Ezcurra and Pascual, 2008; Lessmann, 2009; Rodríguez-Pose and Ezcurra, 2010) have been the object of detailed cross-country and country-based empirical analyses. Microanalyses on the impact of decentralization have also been on the rise. Sepúlveda and Martínez-Vázquez (2011) have analysed how decentralization affects levels of poverty and inequality in a cross-section of countries, while Tselios et al. (2011) have examined its implications for interpersonal inequality across European regions and Morelli and Seaman (2007) for regions of the UK. De Mello (2011) has looked at how decentralization influences social capital.

However, it may be the case that focusing on the implications of decentralization for overall economic growth and territorial disparities, as well as for poverty, interpersonal 
inequality and social capital could be somewhat missing the point. Despite an increasing tendency to justify decentralization on economic grounds (Rodríguez-Pose and Sandall, 2008), the primary aim of transferring powers and resources to subnational tiers of government has never really been about delivering greater growth, lower within country regional inequalities, increasing social capital, tackling poverty, and/or reducing interpersonal inequality. While these factors may certainly be an indirect consequence of decentralization, the original aim of decentralization is fundamentally to improve the delivery of public goods and services to individuals by the creation of more legitimate tiers of government, closer to the people and, therefore, more responsive to their needs and wants. Decentralization is thus first and foremost about improving the delivery of public policies and, consequently, the level of satisfaction of the population with government.

Yet, whether decentralization yields more or less satisfaction with government and public policies has been completely overlooked by the literature. The studies dealing with these issues are few and far between. In spite of the recent boom in the literature on subjective well-being (SWB) and happiness, only a limited number of papers have concentrated on the implications of decentralization for happiness (e.g. Frey and Stutzer, 2000, 2002; Bjørnskov et al., 2008; Voigt and Blume, 2009). To the extent of our knowledge, no paper has analysed how having decision-making and implementation of policies conducted at scales closer to the people affects the level of citizens' satisfaction with democracy, government, the overall economic situation, or with the specific delivery of certain policies, such as education and health. In other words, we seem to know more about how policies and services by subnational governments impinge on aggregate growth and territorial disparities, on poverty and interpersonal 
inequality, than about whether having decision-making conducted closer to the people leads to a population more satisfied with government, and, consequently, to happier citizens.

The aim of this paper is to cover this important gap in the literature by precisely looking at how different levels of decentralization across European countries influence the satisfaction of individuals with democracy, government, the economic situation, the education and health systems and whether decentralized governments affect the overall happiness of citizens. In order to do this, we resort to micro data, consisting of more than 160,000 observations, coming for the four available waves of the European social survey (2002, 2004, 2006 and 2008) for 29 countries in Europe. After controlling for a series of personal characteristics that may affect individual levels of happiness and wellbeing, the results of analysis reveal that happiness, as well as the perception of the state of the health services and satisfaction levels with the government are affected by the degree of decentralization, but are also sensible to the balance between political and fiscal decentralization in any given country. As a general rule, people living in countries with a high level of political and fiscal decentralization tend to be more satisfied with democracy, as well as with the delivery of specific public policies (and, primarily, health). They also tend to be happier. The effect of fiscal decentralization seems to be stronger than the one exerted by political decentralization, especially regarding the satisfaction with government and the economic situation of the country, as well as the state of the education system, where political decentralization does not have any effect.

The remainder of the paper is structured as follows. Section 2 looks first at the factors identified in the literature as driving happiness, before covering the theoretical links 
between decentralization and subjective well-being. Section 3 presents the empirical framework and data, while section 4 explains the results of the empirical econometric analysis. Section 5 concludes and raises a number of issues for further research.

\section{Decentralization and subjective well-being}

\subsection{The factors driving happiness}

Frey and Stutzer (2000) differentiate between three sets of sources of individual wellbeing $^{1}$ : a) personality and demographic factors, such as age, gender, level of education, political and religious orientation, size of household, marital or civil status, and level of health; b) micro- and macroeconomic factors, such as income, unemployment and inflation; and c) institutional or constitutional conditions, with democracy and level of subnational autonomy being two of the most important institutional factors.

There has been no shortage of analyses concerning the influence of the former two factors on individual well-being. The vast majority of studies have concentrated on personality and socio-demographic traits, generally reconciling psychology with economics (Diener et al, 1999). In this literature, the concept of subjective well-being (SWB) tends to be interchangeable with those of happiness or life satisfaction. Happiness or SWB is constructed by asking individuals to choose a point in an ordinal scale regarding their level of happiness or life satisfaction. One problem derived from the use of this type of variable in economics is the fact that one of the components of happiness is affective, i.e. hedonic evaluation guided by emotions and feelings, and this component of the variable is usually unobservable. The other key component of

\footnotetext{
${ }^{1}$ These three sources were later expanded to six: personality, contextual, demographic, environmental, economics and institutional factors (Frey and Stutzer, 2002).
} 
happiness is cognitive, i.e. an information-based appraisal of one's life (Diener, 1994). This component of happiness or SWB can convey information not only about the extent to which one's life fits one's own expectations, but also about the effect of observable and measurable factors on the gap between experienced life and expected life.

Numerous personality and socio-demographic characteristics have been identified as having an important influence on happiness and SWB. Age is possibly the most prominent of these factors. There seems to be a U-shaped relationship between age and happiness. The SWB of an individual tends to decline from youth to middle age, reaching a nadir around mid-forties to mid-fifties, before starting to rise again (Gerdtham and Johannesson, 2001; Blanchflower and Oswald, 2004, 2008). Pure personal traits such as the propensity to smile or signs of cheerfulness are also associated with happiness and SWB (Frey and Stutzer, 2002; Layard, 2005), as are trust and trustworthiness (Helliwell and Wang, 2010). Marital status also matters. Being married seems to have strong positive effects on well-being (Glenn and Weaver, 1988; Gerdtham and Johannesson, 2001). These effects have even been given a monetary value, estimated at $\$ 100,000$ a year relative to widowhood (Blanchflower and Oswald, 2004). Marriage also trumps cohabiting as a source of happiness (Kim and McKenry, 2002), despite the fact that it has been reported that the positive relationship between marriage and happiness has been declining over time in countries like the USA (Glenn and Weaver, 1988). Health is a further factor associated with greater happiness. Healthier people tend to be happier than people with self-reported health problems (Gerdtham and Johannesson, 2001; Frey and Stutzer, 2002). And there seems to be a positive relationship between levels of education and SWB (Gerdtham and Johannesson, 2001; Oreopoulos, 2007). 
Although traditionally there have been less studies about the link between micro- and macroeconomic factors and SWB, this area of research has caught up in recent years. Analyses of the influence of income on happiness have been the stars in this field. Easterlin (1974, 1995) led the way. Others (e.g. Gerdtham and Johannesson, 2001; Blanchflower and Oswald, 2004) followed. The positive but fairly small relationship between income and happiness detected by Easterlin has been corroborated by later studies, as is the case of what is known as Easterlin's paradox, which states that within a country richer people tend to be happier than poorer people, but higher levels of aggregated income in a nation do not necessarily lead to higher levels of aggregated happiness in the country (Easterlin, 1794 and 1995). Moreover, the positive effect of income on happiness seems to be undercut by the parallel rise of aspirations as income rises (Easterlin, 2001). Next to income, other economic factors are known to affect happiness. Clark and Oswald (1994), Oswald (1997), and Wolfers (2003), among others, have identified a strong negative effect of unemployment on happiness. Di Tella et al. (1997) found a negative link between inflation and subjective well-being. The same authors also discover a connection between unemployment, inflation and happiness. They estimate that a one point increase in unemployment has double the negative impact on happiness as a one point increase in inflation (Di Tella et al., 2001). Diaz-Serrano (2009) and Diaz-Serrano and Stoyanova (2010) used panel micro-data to report a significant positive effect of homeownership and the housing environment, respectively, on subjective well-being.

\subsection{Decentralization and subjective well-being}


In contrast with the already vast and growing literature devoted to the study of the personal, socio-demographic and economic determinants of SWB, the number of studies concerned with how institutional factors affect SWB is, despite its policy relevance, extremely limited. The handful of studies devoted to these topics tend to agree that institutions matter for SWB and that happiness is strongly determined by the institutional context (Frey and Stutzer, 2002; Bjørnskov et al., 2010). Other studies, such as Radcliff (2001), go slightly beyond and uncover a positive relation between the ideological complexion of government and some features of the welfare state and levels of SWB, while Veenhoven (2000) finds that political and private freedom exert a positive effect on SWB, but only in rich countries. In addition, the type of institutions that determine happiness may be influenced by the level of development of a country. Bjørnskov et al. (2010) indicate that while in the case of low-income countries economic and judicial institutions may have a greater influence on individual happiness, in medium- and high-income countries political institutions may be more relevant. But beyond these general factors little is known about how institutions actually affect individual happiness.

Given the dearth of institutional analyses of SWB, it comes as no surprise that the studies looking at the link between decentralization and happiness - despite the fact that the global drive towards devolution is one of the most, if not the most, relevant political institutional change of our times (Rodríguez-Pose and Gill, 2003; Hooghe et al. 2008) has attracted virtually no attention. Among the less than a handful of authors who have delved into this topic, three studies stand out. First, Frey and Stutzer (2000) carried out a cross-regional analysis for Switzerland. Their analysis found a positive and highly statistically significant effect of institutional factors, such as government initiatives and 
referenda (as proxies of the functioning of democracy) and local autonomy, on selfreported individuals' well-being. Their interpretation was that decentralization led to a closer match between political outcomes and voters' preferences, thus raising SWB. Bjørnskov et al. (2008) used the world values survey in 66 countries in order to estimate the impact of fiscal and political decentralization on subjective well-being. Their results showed that local budgets and their size mattered for well-being. More recently, Voigt and Blume (2009) find a positive correlation between happiness and federalism in a cross-country assessment, which may compensate for higher budget deficits and lower government expenditure in federations.

One of the problems with these analyses is that they make an important leap from decentralization to SWB, without a clear theoretical justification. Although there is no doubt that better-functioning institutions may have an impact on overall individual happiness, the effect is bound to be indirect rather than direct: if local and regional governments are more responsive to the needs of local citizens than national governments, they will deliver public goods and services more efficiently, leaving citizens more satisfied with public policies and thus with their governments and with their level of democracy. And greater satisfaction with these aspects may result in greater happiness. That is, SWB may be an indirect cause of decentralization, with better policies and the resulting greater citizen satisfaction with policies being the direct consequence. Yet, to the extent of our knowledge, no study has so far addressed whether decentralization leads to greater individual satisfaction with aspects that are directly related to the effectiveness, or lack of it, of the policies implemented by decentralized governments. 
The reasons for this absence are twofold. First, while the information of SWB has kept on improving in recent years, similar information on individual satisfaction with political institutions and the effectiveness of policies has been more limited, although not inexistent. Second and perhaps more importantly, the theoretical links between local autonomy, satisfaction with political institutions and happiness are, as indicated by Bjørnskov et al. (2008), still underdeveloped.

We address the former issue by resorting to information on personal satisfaction with policy and politics and happiness stemming from the European Social Survey (ESS). But before jumping into the analysis, it is necessary to discuss the latter shortcoming, that of the link between decentralization and the level of satisfaction with political institutions.

As highlighted Bjørnskov et al. (2008: 147), the arguments about whether local autonomy leads to greater satisfaction with public policies, in particular, and political institutions, in general, are closely related to the general arguments for and against decentralization. Both positive and negative arguments are linked with the fundamental change in scale for the delivery of policies that greater local autonomy entails. In centralised governments policy-makers cater for the whole country with their decisions, but centralised decisions may benefit certain individuals and regions at the expense of others, especially in the case of large and heterogeneous countries. Hence, the chance of covering diverse needs and wants is somewhat limited by the requirement to deliver overall efficiency and is likely to leave a large percentage of the population dissatisfied with public policies and government. The shift in scale of decision-making, which is the essence of decentralization, implies that governments have a greater potential to tailor 
their specific policies to the needs of citizens. This is what is known as the 'fiscal decentralization theorem' (Tiebout, 1956; Klugman, 1994): a better matching of public goods and services delivery to the needs of citizens leads, ceteris paribus, to greater satisfaction with policy.

The shift in the scale also engenders greater competition among local governments to deliver better goods and services (Hayek, 1939; Tiebout, 1956). The possibility of people 'voting with their feet' (Tiebout, 1956) and the lower cost of migration across local and regional jurisdictions within a country act as an incentive for governments to both respond better to the demands of citizens and to improve the policy delivery, possibly leading to increased citizen satisfaction.

Territorial competition for the provision of policies is intrinsically linked to greater policy innovation (Rodríguez-Pose and Gill, 2005). Local governments, in their quest to be more responsive, are bound to be more creative and innovative in pursuing policies that satisfy the needs of their citizens (Oates, 1972; Donohue, 1997). Successful innovations in one territory can then be transferred and adapted to the needs of local citizens in other locations (Donohue, 1997).

Last but not least, the act of enhancing local autonomy implies greater accountability and transparency of government. It also gives individuals greater voice and a greater chance to participate and influence the design and implementation of policies. Citizens can interact better with governments and better scrutinize their actions, bringing governments and those governed closer to one another (Putnam 1993; Azfar et al. 1999), possibly enhancing the level of citizen satisfaction with political organizations 
and public policies. Decentralization also reduces transaction costs and, provided wellfunctioning institutions, it may also reduce the risk of elite capture of rents (Inman and Rubinfeld 2000; Storper 2005).

The other side of the coin is, however, that while decentralization may set free a number of mechanisms likely to enhance citizen satisfaction, it may also trigger other processes that could undermine the very satisfaction with politics and policy it aims to achieve. It may be the case, as Prud'homme (1995) underlines, that the supposedly greater capacity by local governments to adapt their policies to local needs may be nothing but a pipe dream. Two reasons are behind this potential incapacity of local governments to better respond to citizens' demands. First, individual needs and wants may not vary significantly from one place to another. As Prud'homme underlines, local governments may end up having to satisfy basic needs "which are - at least in principle - quite well known" (1995: 208). The needs of access to food, a decent education, adequate health care, basic infrastructure and basic services are universal and unlikely to change across territories. Hence, in trying to satisfy these needs, local governments may be at a disadvantage with respect to national governments, as they may lack the economies of scale, the resources or the capacity - or, often all three of them - to address all basic needs adequately, resulting in lower satisfaction with decentralized governments.

Local governments in lagging regions may also suffer from capacity constraints. Poorly trained decision-makers and officials may undermine the capacity of local governments to adequately respond to the needs of citizens (Prud'homme, 1995). Capacity constraints by local governments will thus not only reduce the potential satisfaction with the policies they deliver, but may also contribute to facilitate special-interest 
capture by local elites, further limiting the potential of local policies to reach as wide a section of the local population as possible (Inman and Rubinfeld, 2000; Storper, 2005).

Whether the positive or negative mechanisms which affect a citizen's level of satisfaction with policy and political institutions in a decentralized setting prevail depends on one key additional factor: that of whether the resources of local governments match their needs. The frequent mismatch between the powers of local governments and the resources at their disposal, especially in cases where decentralization has been promoted 'from above' - that is by the central government, rather than by local demand - will contribute to an inadequate delivery of goods and services by local governments (Rodríguez-Pose and Gill, 2003). 'Unfunded mandates' by local governments are likely to dent the levels of citizen satisfaction with local governments. It is therefore important to distinguish between the political powers of decentralized governments (political decentralization) and the funds to implement independent policies (fiscal decentralization), as they are not always correlated and have important implications for the level of satisfaction with decentralization.

\section{Empirical framework and data}

In order to determine whether the aspects linked to decentralization lead to a greater or lower citizens' satisfaction, our analysis examines how cross-country differences in political and fiscal decentralization (key independent variables) affect the level of satisfaction of individuals with democracy, government, the economic situation, the education and health systems, and their overall levels of happiness (dependent variables). 


\subsection{The dependent variables: overall happiness and satisfaction with institutions}

\section{and policy}

Our dependent variables stem from the four waves of the European Social Survey (ESS) that have been made available. This biannual cross-national survey aims to create a standard of methodology for cross-national attitude surveys. Its main focus are people's attitudes and underlying values, but it also contains a number of social background variables on individuals, as well as on their partners and parents. The available survey years are 2002, 2004, 2006 and 2008. In order to maximize the number of observations by country and introduce also a temporal dimension to the data, we pool the four available waves of the ESS.

The ESS consists of regular 'rounds' of data collection, with each round involving an independent cross-sectional sample in each nation. The target population for each participating nation is defined as all adults (15 years or older) resident in private households within the borders of the nation, regardless of nationality or citizenship. The geographic coverage in the four available waves refers to 30 (mostly) European countries. Table 1 depicts the sample, including the number of observations per country in each wave.

Table 1 [around here]

One of the most important features of the ESS questionnaire is that it contains both fixed and rotating elements. In the rotating part of the questionnaire, every wave includes two specific topics that can change from wave to wave. The fixed part consists of questions that are included in every ESS-wave. This module includes basic socio- 
economic and demographic background information, but also some questions regarding respondents' satisfaction in different domains. We use these variables to measure the impact of government decentralization on individual's subjective well-being. More specifically our outcome variables regard the following satisfaction domains: happiness, present state of the economy, satisfaction with government and satisfaction with democracy, state of education and state of health services. Elicited individuals' responses are based on an eleven-point scale where 0 means extremely bad/dissatisfied and 10 means extremely good/satisfied. In Table 2 we show the summary statistics of the satisfaction variables used in the analysis. As the variable depicting the degree of an individual's happiness refers to the same concept as an individual's life satisfaction, we only use the former as an indicator of the level of an individual's subjective well-being (SWB).

Table 2 [around here]

The five Nordic countries report the highest levels of SWB. There are a significant number of countries with a low level of SWB, i.e. average scores below seven (Table 2). These countries are in Southern - with the exception of Spain - and Eastern Europe. Looking at the remaining satisfaction with government and institutions domains, we can distinguish between two groups of countries. One group is made of countries where their citizens exhibit a high degree of satisfaction with institutions. This group encompasses, once again, the Nordic and Western European countries. At the opposite end, we find Eastern European countries plus Portugal.

\subsection{Main independent variables: the decentralization data}


The decentralization variables are divided, following the theoretical discussion, into political and fiscal decentralization variables. They stem from two different sources. Political decentralization indicators are taken from Hooghe et al.'s (2008) Regional authority index (RAI). The data covers 42 countries for the period 1950-2006. The RAI is measured along eight dimensions, blending different aspects of decentralization.

In addition to Hooghe et al.'s (2008) data, we also use specific data on fiscal decentralization. These data consist of indicators calculated as the ratio between subcentral and general economic magnitudes. These are yearly indicators covering the period 1972-2005. The source of these variables is the Government Finance Statistics of the International Monetary Fund. We use five indicators covering the following five economic dimensions: expenditure, current expenditure, capital expenditure, revenues/grants and tax revenues. The specific decentralization variables are defined in Table 3.

Table 3 [around here]

\subsection{Matching ESS and decentralization data}

In order to test the impact of decentralization on an individual's subjective well-being (SWB), we match the ESS with the decentralization variables. All individuals surveyed in the ESS and residing in the same country are assigned the same value of the corresponding decentralization index. Since the individual data used here pool the four waves of the ESS, the decentralization variables vary not only by country but also by wave. For any country, we assign the time-average of the last ten years prior to the survey of a given decentralization measure. For the 2008 wave, we resort to the 
decentralization indicators in 2006. We proceed in this way because the latest available years for our decentralization measures are 2005 and 2006 for the fiscal decentralization and the RAI dataset, respectively. In Table 4, we rank the countries included in our sample according to their level of decentralization.

According to the RAI index, the top five politically decentralized countries are Germany, Belgium, Spain, Switzerland and Italy. At the bottom of the ranking we find relatively small countries, such as Iceland, Luxembourg, Estonia, Cyprus, and Slovenia. The specific fiscal decentralization measures provide a different ranking: the top five fiscally decentralized countries include Switzerland, Germany, Denmark, Sweden and Belgium. Israel, Luxembourg, Portugal, Iceland and Bulgaria are at the bottom of this ranking. Recall that the fiscal decentralization index reported in Table 4 is the average of the five fiscal decentralization indexes used in the analysis (see Table 1).

Table 4 [around here]

\subsection{Empirical framework}

In our econometric analysis we resort to the use of pooled cross-sections referring to different years. This approach allows us to introduce a temporal dimension in the empirical model. That is, decentralization measures not only vary by country, but also with time. Our outcome variables are individuals' self-reported subjective indicators. This circumstance implies that the effect of the country level covariates on the outcome is more sensible to vary, in some cases in a non-negligible way, in different periods of

time. An economic or institutional shock in a country in a given period of time may cause a change in the self-perception of an individual's well-being or of the state of 
public institutions and services. This shock will remain unobservable and may bias the estimated effects of the country level indicators on the outcome variables, i.e. a statistically significant effect may turn out to be not significant. One way to take into account these changes in the self-perception of an individual's well-being, and hence of smoothing the potential bias they may cause on the estimated parameters, consists of including this temporal dimension.

Considering the temporal dimension in the model implies introducing not only specific country effects, but also specific country-time effects, as the decentralization measures vary by country and year. We thus consider that the propensity in a period $t$ of individual $i$ residing in country $c$ to report a specific SWB status or self-perceived state of an institution or service is determined by the following linear relationship:

$$
S_{i c t}^{*}=\beta^{\prime} X_{i c t}+\gamma^{\prime} Z_{c t}+u_{c t}+\varepsilon_{i c t}
$$

where $S_{i c t}^{*}$ is a latent outcome, $X_{i c t}$ are a set of individual's characteristics, $Z_{c t}$ are the country-specific variables, $u_{c t}$ are crossed country-time specific effects, $\varepsilon_{i c t}$ is a random error term, and $\beta$ and $\gamma$ are a set of parameters to be estimated. $u_{c t}$ are necessary in order to disentangle the effect of the specific-country variables, $Z_{c t}$.

In equation (1), we do not observe $S_{i}^{*}$ but instead an indicator variable of the type $S_{i c t}=j$ if $\mu_{j-1}<S_{i c t}^{*} \leq \mu_{j}(j=1, \ldots, J)$. Given the ordinal nature of the outcome variable, a natural option to estimate model (1) is the ordinal probit/logit model with specific 
country-time random effects. An alternative, less computationally demanding, option is the Probit Ordinary Least Squares model (Van Praag and Ferrer-i-Carbonell, 2006). ${ }^{2}$

After transforming our outcome variables, we estimate equation (1) by means of a linear random-effects model. We cluster at the country-year level, which takes account of intra-group correlation, but equally corrects for heteroscedasticity. In equation (1), the covariates contained in matrix $X_{i c t}$ are a set of individual characteristics, including the squared polynomial of age, gender, education level, citizenship, self-reported health status, religious level, left-right political position, marital status, feeling about household income and household size. The country-specific variables included in $Z_{c t}$ are the decentralization measures described in Table 3, which are entered in equation (1) separately one by one. The individual variables mentioned above are described in table 5 and summarized by country in Table 6.

Table 5 [around here]

Table 6 [around here]

\section{Results of the analysis}

\subsection{Individual factors}

Table 7 reports the results of the estimation of equation (3) for our six outcome variables: overall happiness, on the one hand, and satisfaction with the overall economic situation, government, democracy, the educational system, and public health services, on the other.

2 This framework involves the transformation of the observed ordinal outcome $S_{i c t}=j$ as $\ln \left(Z_{i c t}\right)=\left[\phi\left(\mu_{j-1, t}\right)-\phi\left(\mu_{j, t}\right)\right] /\left[\Phi\left(\mu_{j, t}\right)-\Phi\left(\mu_{j-1, t}\right)\right]$, where $\phi(\bullet)$ and $\Phi(\bullet)$ are the normal density function and the cumulative normal distribution, respectively. This transformation enables moving from the ordinal probit framework to the simple linear OLS approach without any loss of efficiency. 
The top half of Table 7 depicts the results for the individual features which may affect SWB and levels of satisfaction. These results are virtually all statistically significant and, by and large, reproduce those of previous empirical analyses, underlining the robustness of the exercise. First, age matters for happiness and satisfaction with institutions and policies. SWB and satisfaction tend to decrease with age, but the relationship is U-shaped, as happiness and satisfaction increase after middle-age. Women tend to be happier, but less satisfied than men with institutions and with the economic situation, democracy and the health system, in particular. Also as expected, married people tend to report greater levels of overall happiness and satisfaction that those separated, divorced, widowed or never married. The only partial exception are widowed individuals, who, once controlled for everything else, have levels of satisfaction with government, democracy and the health system that are similar or superior to those married. Higher levels of education yield happier people, but more critical with the state of democracy, the economy and the delivery of public services. Health is also an important determinant of happiness and satisfaction. The lower the level of self-reported health, the lower the SWB and the satisfaction with institutions. Larger households tend to be happier, but, with the exception of the state of the health system, not necessarily more or less satisfied with institutions than smaller households. Right-leaning individuals are also happier and generally more satisfied with institutions and the state of public services than left-leaning ones. Foreigners are happier than those holding national passports, but not more satisfied with public services. And, as could be expected, those who report that they live comfortably are happier and more satisfied than those who consider that they are in a very difficult or difficult position or simply coping. 
The strongest associations with happiness and satisfaction with institutions come from two variables: religiosity and trust. Religious individuals, regardless of the denomination of their church, tend to be significantly happier, when other factors are controlled for, than those with a lower level of religiosity. And trusting individuals reinforcing the strong effects of Helliwell and Wang (2010) - reveal themselves as the happiest and most satisfied of all.

The distinction between overall happiness and satisfaction with particular institutions is also an important one. While age, marital status, self reported health, feeling about household income, trust, religiosity, and political orientation exert the same effect on the different satisfaction domains as on happiness, gender, education and citizenship tend to have opposite effects.

\subsection{The effect of decentralization on happiness and satisfaction with institutions}

Having controlled that our results conform with previous analyses of the personality and socio-demographic traits behind happiness and institutional satisfaction, in the bottom half of Table 7 we now turn to how political and fiscal decentralization indicators affect these factors. In order to allow for comparisons across alternative models, in Table 8 we report the elasticities for the decentralization indicators.

Our estimates show that greater political local autonomy matters for overall happiness, but the impact on the satisfaction of individuals with political institutions and public polices is limited to a few domains. Political decentralization has a significant and positive effect on happiness, but leads to greater satisfaction only with democracy and 
the health system. For democracy, the significant positive effect is only observed for the indicator reflecting the degree of the authority exercised by a regional government over those who live in the region (self-rule) and also for the overall political decentralization indicator (Regional Authority Index, RAI). In contrast, there is no statistically significant association between greater regional and local autonomy and satisfaction with the state of the economy, with government or with the education system (Table 7).

If we focus on the specific constituents of political decentralization, the RAI significantly raises happiness, satisfaction with democracy and satisfaction with the state of the health services in the country. It is in this latter domain where the RAI has the largest effect: a $10 \%$ increase in the RAI index triggers a $1.3 \%$ increase in an individual's satisfaction with the health system. The three aggregated decentralization indexes - self-rule, law making and shared-rule - also exhibit an effect on happiness and satisfaction with the health system, although the effect is considerably greater for the latter variable. As mentioned above, the significant positive impact of RAI on satisfaction with democracy is mediated exclusively by self-rule (Table 7).

Table 7 [around here]

Of the six dependent variables considered, satisfaction with the state of health services and satisfaction with democracy display a greater sensitivity to political decentralization, followed by overall happiness. This implies that political decentralization seems to have a much greater effect on those variables that affect the perception of individuals about the more abstract political institutions (e.g. democracy) and, through them, on overall SWB. In contrast, whether policies are conducted at a 
local, regional or national scale does not affect, either positively or negatively, individual perceptions about the government or the economy.

Fiscal decentralization also has a significant effect on overall happiness. In addition, the effect of fiscal decentralization on the level of satisfaction with political institutions is stronger than that identified for political decentralization. With only two exceptions, all fiscal decentralization indexes are statistically significant at the one percent level in all the satisfaction regressions. Fiscal decentralization is a key determinant of satisfaction with the economic situation, with government and with the state of the education system, whereas political decentralization is not (Table 7). The subnational expenditure variables are more important than the subnational revenue variables in predicting SWB. With few exceptions, this is also the case for individual satisfaction with institutions. More specifically, subnational government expenditure is by far the variable that exerts the strongest effect on SWB and all satisfaction domains with institutions, followed by the estimated effect of subnational capital expenditure. However, as pointed by Rodríguez-Pose et al. (2009), decentralization processes in Europe and elsewhere in the world, have tended to lead to increases in current expenditure at the expense of capital expenditure. The dependent variables which exhibit a greater response to the specific indexes of fiscal decentralization are satisfaction with state of the health and education systems, followed by the observed satisfaction with government, democracy and the economic situation. The different influence of political and fiscal decentralization on the levels of satisfaction with the education system indicate that citizens seem to prefer a better resourced education system, regardless of whether the political decisions are taken at the local or at the national level. 
The combination of the positive effect of political and fiscal decentralization variables on happiness is an interesting one. Citizens seem to be happy not only with the transfer of resources, which indicates the capacity of local governments to implement policies, but also with the ability to conduct policies at the local level, represented by the transfer of powers to subnational governments. However, the greater influence of fiscal in comparison to political decentralization variables on the degree of satisfaction with institutions and public policy signals that citizens value more the transfer of resources than the capacity of local governments to implement policies. The association between greater local and regional autonomy and happiness is also, with the exception of satisfaction with the health system, more strongly associated with more abstract constructs, such as satisfaction with government or democracy or overall happiness, than with more concrete ones, such as satisfaction with the economy or with the education system. The fiscal dimension, which represents a more concrete dimension of decentralization, is entirely connected with satisfaction and happiness. Overall, citizens seem to be happier with the actual capacity of their local governments to deliver than with the fact that they can have a say on their daily politics and policies.

Table 8 [around here]

\section{Conclusions}

This paper has tackled a number of black boxes about the influence of decentralization processes. First, it represents a step beyond the studies about the macroeconomic and territorial impacts of decentralization which have dominated analyses of fiscal decentralization. Second, it has delved into the little known world of the institutional

conditions influencing SWB, which had been obscured by the prominence of analyses 
focused on personal, socio-demographic and micro- and macroeconomic factors. Third, it goes beyond the point, underlined by Frey and Stutzer (2002), that happiness is much more than personal issues, by paying attention to the distinction between overall SWB and the level of satisfaction with political institutions and policy. This implies taking into account that changes in the satisfaction with political institutions ultimately contribute to enhance or hurt overall happiness. It also resorts to the use of a temporal dimension in order to consider any potential shocks that may affect the self-perception of an individual's well-being. Finally, it distinguishes between the political and fiscal dimensions of decentralization - and among its various constituents - in order to present a fuller picture of the mechanisms at work in determining the satisfaction with changes in the dimension of political institutions.

The results highlight that both political and fiscal decentralization matter, but that it is this latter dimension of decentralization which seems to be more relevant for citizens. Decentralization matters positively for the satisfaction of individuals with political institutions and with the specific delivery of some public goods and services. This represents an important contrast to the traditional analyses of the macroeconomic implications of decentralization, which tend to point to an either negligible or negative influence of decentralization on factors such as economic growth and productivity, fiscal policy or government effectiveness (e.g. Voigt and Blume, 2009; Rodríguez-Pose and Ezcurra, 2011; Schnellenbach and Feld, 2011). The results also signal that many of these studies may be somewhat off-focus, as the ultimate goal of decentralization, is not necessarily to deliver better aggregate economic outcomes but to improve the delivery of policies and services and to make citizens more satisfied. Whether this leads to better macroeconomic outcomes will then depend on the actual capacity of local governments 
to deliver. This subtle distinction is captured in the analysis by the different results for political and fiscal decentralization. Citizens are satisfied and happier with the thought that decisions can be taken by governments closer to them, but their actual capacity to deliver is even more important for their personal satisfaction.

The analysis also raises a number of interesting issues that will need to be tackled as the conceptual tools and the data improve. Although we capture some temporal dimension, the analysis is not a true panel. Improvements in the collection of data on personal satisfaction and the generation of true panels will certainly put our results to the test. We also consider that disentangling the mechanisms through which institutional satisfaction is linked to overall happiness will require greater detail with more suitable data. In any case, we believe that our results can set the bases for a greater scholarly and policy concern with a capital aspect of decentralization which has so far been neglected by most traditional studies on the transfer of powers and resources to subnational tiers of government. 


\section{References}

Azfar, O., Kähkönen, S., Lanyi, A., Meagher, P. and Rutherford, D. (1999) Decentralization, Governance and Public Services. The Impact of Institutional Arrangements: A Review of the Literature, Working Paper 255, IRIS Center, University of Maryland, College Park.

Bjørnskov, C., Drehe, A. and Fischer, J.A.V. (2008) On decentralization and life satisfaction. Economics Letters 99 (1): 147-151.

Bjørnskov, C., Drehe, A. and Fischer, J.A.V. (2010) Formal institutions and subjective well-being: revisiting the cross-country evidence. European Journal of Political Rconomy, 26: 419-430.

Blanchflower, D.G. and Oswald, A.J. (2004) Well-being over time in Britain and the USA. Journal of Public Economics 88 (7-8): 1359-1386.

Blanchflower, D.G. and Oswald, A.J. (2008) Is well-being U-shaped over the life cycle? Social Science and Medicine 66 (8): 1733-1749.

Clark, A.E. and Oswald, A.J. (1994) Unhappiness and Unemployment. Economic Journal 104 (424): 648-659.

Davoodi, H. and Zou, H. (1998) Fiscal decentralization and economic growth: a crosscountry study. Journal of Urban Economics 43:, 244-257.

De Mello, L. (2011) Does Fiscal Decentralization Strengthen Social Capital? CrossCountry Evidence and the Experiences of Brazil and Indonesia. Environment and Planning C: Government and Policy 29 (2) forthcoming.

Di Tella, R., MacCulloch R.J. and Oswald A.J. (1997) The Macroeconomics of Happiness, Discussion Paper No. 19, Centre for Economic Performance, University of Oxford. 
Di Tella, R., MacCulloch R.J. and Oswald A.J. (2001). Preferences over inflation and unemployment: Evidence from surveys of happiness. American Economic Review 91 (1): 335-41.

Diaz-Serrano, L. (2009) Disentangling the Housing Satisfaction Puzzle: Does Homeownership Really Matter? Journal of Economic Psychology 30(5): 745755.

Diaz-Serrano, L. and Stoyanova, A.P. (2010) Mobility and Housing Satisfaction: an Empirical Analysis for Twelve EU Countries. Journal of Economic Geography 10 (5): 661-683.

Diener, E. (1994) Assessing Subjective Well-Being: Progress and Opportunities. Social Indicators Research 31 (2): 103-157.

Diener, E., Suh E.M., Lucas R.E., and Smith H.L. (1999) Subjective Well-Being: Three Decades of Progress. Psychological Bulletin 125 (2): 276-303.

Donahue, J.D. (1997) Disunited States. New York: Basic Books.

Easterlin, R.A. (1974) Does Economic Growth Improve the Human Lot? Some Empirical Evidence', In P. A. David and M. W. Reder (eds) Nations and Households in Economic Growth: Essays in Honour of Moses Abramowitz, New York and London: Academic Press, pp. 89-125.

Easterlin, R.A. (1995) Will Raising the Incomes of All Increase the Happiness of All? Journal of Economic Behaviour and Organization 27(1): 35-48.

Easterlin, R.A. (2001) Income and Happiness: Towards a Unified Theory. The Economic Journal 111: 465-484.

Ezcurra, R. and Pascual, P. (2008) Fiscal decentralization and regional disparities: evidence from several European Union countries. Environment and Planning A 40 (5): 1185-1201. 
Frey, B.S. and Stutzer, A. (2000) Happiness, Economy and Institutions. The Economic Journal 110 (466): 918 - 938.

Frey, B.S. and Stutzer, A. (2002) Happiness and Economics: How the Economy and Institutions Affect Human Well-being, New Jersey: Princeton University Press.

Gerdtham, U.G. and Johannesson, M. (2001) The relationship between happiness, health, and socio-economic factors: results based on Swedish microdata. Journal of Socio-Economics 30 (6): 553-557.

Gil Canaleta, C., Pascual Arzoz, P. and Rapún Gárate, M. (2004) Regional economic disparities and decentralization. Urban Studies 41(1): 71-94.

Glenn, N. and Weaver, C. (1988) The changing relationship of marital status to reported happiness. Journal of Marriage and the Family 50: 317-324.

Hayek, F. von (1939) Economic conditions of inter-state federalism. New Commonwealth Quarterly S. 131-49.

Helliwell, J.F. and Wang S. (2010) Trust and well-being. NBER Working Paper 15911.Cambridge: National Bureau of Economic Research

Hooghe, L., Marks, G. Schakel, A.H. (2008) Regional Authority in 42 Democracies, 1950-2006. A Measure and Five Hypotheses. Regional and Federal Studies 18 (2-3): 111-302.

Iimi, A. (2005) Decentralization and economic growth revisited: an empirical note, Journal of Urban Economics 57: 449-461.

Inman, R.P. and Rubinfeld, D.L. (2000). Federalism. In: B. Bouckaert and G. de Geest (eds.). Encyclopedia of Law and Economics. Edward Elgar and the University of Ghent. 
Kim, H.K. and McKenry, P. (2002) The Relationship Between Marriage and Psychological Well-being: A Longitudinal Analysis. Journal of Family Issues 23(5): 885-911.

Klugman, J. (1994) Decentralization: A survey of literature from a human development perspective. New York: United Nations Development Programme Occasional Paper 13 Human Development Report Office.

Layard, R. (2005) Happiness: Lessons from a New Science. London: Penguin

Lessmann, C. (2009) Fiscal decentralization and regional disparity: evidence from cross-section and panel data. Environment and Planning A 41(10): 2455-2473.

Morelli, C. and Seaman, P. (2007) Devolution and Inequality: A Failure to Create a Community of Equals? Transactions of the Institute of British Geographers $32: 523-538$

Oates, W.E. (1972) Fiscal Federalism. New York: Harcourt-Brace-Jovanovich.

Oreopoulos, P. (2007) Do dropouts drop out too soon? Wealth, health and happiness from compulsory schooling. Journal of Public Economics 91 (11-12): 22132229.

Oswald, A.J. (1997) Happiness and Economic Performance. Economic Journal, 107(445): 1815-1831.

Prud'homme, R. (1995) The dangers of decentralization, The World Research Observer 10 (2): 201-220 .

Putnam, R.D. (1993) Making Democracy Work: Civic Traditions in Modern Italy. Princeton, NJ: Princeton University Press, Princeton.

Radcliff, B. (2001) Politics, Markets and Life Satisfaction: The Political Economy of Human Happiness. American Political Science Review 95 (4): 939-952. 
Rodríguez-Pose, A. and Bwire, A. (2004) The economic (in)efficiency of devolution. Environment and Planning A 36 (11): 1907-1928.

Rodríguez-Pose, A. and Ezcurra, R. (2010) Does decentralization matter for regional disparities? A cross-country analysis. Journal of Economic Geography 10(5): $619-644$.

Rodríguez-Pose, A. and Ezcurra, R. (2011) Is fiscal decentralization harmful for economic growth? Evidence from the OECD countries. Journal of Economic Geography, forthcoming. doi:10.1093/jeg/lbq025

Rodríguez-Pose, A. and Gill, N. (2003) The global trend towards devolution and its implications. Environment and Planning C: Government and Policy 21 (3): 33351.

Rodríguez-Pose, A. and Gill, N. (2005) On the economic dividend of devolution. Regional Studies 39: 405-420.

Rodríguez-Pose, A, Tijmstra, S.A.R. and, Bwire A, (2009) Fiscal decentralization, efficiency, and growth. Environment and Planning A 41(9): 2041-2062.

Schnellenbach and Feld (2011) Fiscal Federalism and Long-Run Macroeconomic Performance: A Survey of Recent Research. Environment and Planning C: Government and Policy 29 (2) forthcoming.

Sepúlveda, C. and Martínez-Vázquez, J. (2011) The Consequences of Fiscal Decentralization on Poverty and Income Inequality. Environment and Planning C: Government and Policy 29 (2) forthcoming.

Storper, M. (2005) Society, Community and Economic Development. Studies in Comparative International Development, 39,4: 30-57.

Thießen, U. (2003) Fiscal decentralization and economic growth in high-income OECD countries. Fiscal Studies 24: 237-274. 
Tiebout, C.M. (1956) A pure theory of local expenditures. Journal of Political Economy 64 (5): 416-424.

Tselios, V., Rodríguez-Pose, A., Pike, A., Tomaney, J. And Torrisi, G.P. (2011) Income inequality, regional development, and decentralization in Western Europe, Mimeo.

van Praag, B. and Ferrer-i-Carbonell, B. (2004) Happiness Quantified: A Satisfaction Calculus Approach. Oxford: Oxford University Press.

Veenhoven, R. (2000) Freedom and Happiness: A Comparative Study in Forty-Four Nations in the Early 1990s. In: E. Diener and E.M. Suh (eds.) Culture and Subjective Well-Being. Cambridge MA/London: The MIT Press, 257-288.

Voigt, S. and Blume, L. (2009) The economic effects of federalism and decentralization - A cross-country assessment. CESifo Working Paper No: 2766.

Wolfers, J. (2003) Is business cycle volatility costly? Evidence from surveys of subjective well-being. International Finance 6 (1):1-31. 
Table 1: Number of observations by country and wave

\begin{tabular}{|c|c|c|c|c|}
\hline & 2002 & 2004 & 2006 & 2008 \\
\hline Austria & 2,257 & 2,256 & & \\
\hline Belgium & 1,899 & 1,778 & 1,798 & 1,760 \\
\hline Bulgaria & & & 1,400 & 2,230 \\
\hline Switzerland & 2,040 & 2,141 & 1,804 & 1,819 \\
\hline Cyprus & & & 995 & 1,215 \\
\hline Czech Republic & 1,360 & 3,026 & & \\
\hline Germany & 2,919 & 2,870 & 2,916 & 2,751 \\
\hline Denmark & 1,506 & 1,487 & 1,505 & 1,610 \\
\hline Estonia & & 1,989 & 1,517 & 1,661 \\
\hline Spain & 1,729 & 1,663 & 1,876 & 2,576 \\
\hline Finland & 2,000 & 2,022 & 1,896 & 2,195 \\
\hline France & 1,503 & 1,806 & 1,986 & 2,073 \\
\hline United & & & & \\
\hline Kingdom & 2,052 & 1,897 & 2,394 & 2,352 \\
\hline Greece & 2,566 & 2,406 & & \\
\hline Hungary & 1,685 & 1,498 & 1,518 & 1,544 \\
\hline Ireland & 2,046 & 2,286 & & \\
\hline Israel & 2,499 & & & 2,490 \\
\hline Iceland & & 579 & & \\
\hline Italy & 1,207 & & & \\
\hline Luxembourg & 1,552 & 1,635 & & \\
\hline Netherlands & 2,364 & 1,881 & & 1,778 \\
\hline Norway & 2,036 & 1,760 & 1,750 & 1,549 \\
\hline Poland & 2,110 & 1,716 & 1,721 & 1,619 \\
\hline Portugal & 1,511 & 2,052 & 2,222 & 2,367 \\
\hline Russia & & & 2,437 & 2,512 \\
\hline Sweden & 1,999 & 1,948 & 1,927 & 1,830 \\
\hline Slovenia & 1,519 & 1,442 & 1,476 & 1,286 \\
\hline Slovakia & & 1,512 & 1,766 & 1,810 \\
\hline Turkey & & 1,856 & & \\
\hline Ukraine & & 2,031 & & \\
\hline
\end{tabular}


Table 2: Summary statistics of the satisfaction variables, values are estimated from individual responses and averaged by country.

\begin{tabular}{|c|c|c|c|c|c|c|c|c|c|c|c|c|c|c|c|c|c|c|}
\hline & \multicolumn{3}{|c|}{ Happiness } & \multicolumn{3}{|c|}{ Economic situation } & \multicolumn{3}{|c|}{ Government } & \multicolumn{3}{|c|}{ Democracy } & \multicolumn{3}{|c|}{ State of education } & \multicolumn{3}{|c|}{ State health services } \\
\hline & mean & s.d. & $\overline{r a n k}$ & mean & s.d. & $\overline{r a n k}$ & mean & s.d. & $\overline{r a n k}$ & mean & s.d. & $\overline{r a n k}$ & mean & s.d. & $\overline{\text { rank }}$ & mean & s.d. & rank \\
\hline Austria & 7.53 & 1.94 & 12 & 5.21 & 2.25 & 11 & 4.01 & 2.45 & 21 & 5.83 & 2.39 & 12 & 5.96 & 2.37 & 10 & 6.61 & 2.29 & 4 \\
\hline Belgium & 7.71 & 1.59 & 10 & 5.04 & 2.07 & 12 & 4.72 & 2.08 & 10 & 5.44 & 2.13 & 13 & 6.47 & 2.08 & 5 & 7.23 & 1.72 & 1 \\
\hline Bulgaria & 5.22 & 2.61 & 30 & 2.42 & 1.93 & 30 & 2.44 & 2.21 & 30 & 2.52 & 2.13 & 30 & 3.71 & 2.44 & 30 & 2.92 & 2.37 & 29 \\
\hline Switzerland & 8.01 & 1.50 & 4 & 5.62 & 2.06 & 6 & 5.61 & 1.91 & 6 & 6.66 & 1.99 & 3 & 6.27 & 2.03 & 7 & 6.47 & 2.15 & 6 \\
\hline Cyprus & 7.57 & 1.69 & 11 & 5.23 & 2.18 & 10 & 6.06 & 2.15 & 3 & 6.54 & 2.13 & 5 & 5.96 & 2.09 & 9 & 5.96 & 2.22 & 9 \\
\hline Czech Republic & 6.79 & 2.03 & 19 & 3.68 & 2.20 & 20 & 3.56 & 2.25 & 25 & 4.66 & 2.38 & 21 & 6.15 & 2.09 & 8 & 5.20 & 2.38 & 17 \\
\hline Germany & 7.10 & 1.96 & 18 & 3.68 & 2.25 & 21 & 3.55 & 2.17 & 26 & 5.09 & 2.46 & 15 & 4.37 & 2.20 & 26 & 4.63 & 2.38 & 20 \\
\hline Denmark & 8.33 & 1.39 & 2 & 6.94 & 2.08 & 1 & 5.76 & 2.37 & 5 & 7.35 & 1.91 & 1 & 7.42 & 1.79 & 2 & 6.18 & 2.11 & 8 \\
\hline Estonia & 6.56 & 2.01 & 23 & 4.53 & 2.32 & 16 & 4.06 & 2.27 & 18 & 4.63 & 2.31 & 22 & 5.60 & 2.19 & 12 & 4.50 & 2.32 & 21 \\
\hline Spain & 7.50 & 1.72 & 13 & 4.63 & 2.11 & 14 & 4.49 & 2.23 & 14 & 5.86 & 2.08 & 10 & 5.16 & 2.08 & 19 & 5.84 & 2.16 & 11 \\
\hline Finland & 8.03 & 1.43 & 3 & 6.39 & 1.81 & 4 & 6.06 & 1.88 & 2 & 6.58 & 1.88 & 4 & 7.85 & 1.41 & 1 & 6.77 & 1.94 & 3 \\
\hline France & 7.19 & 1.84 & 16 & 3.47 & 2.06 & 25 & 4.03 & 2.20 & 19 & 4.68 & 2.34 & 20 & 4.99 & 2.12 & 22 & 5.93 & 2.22 & 10 \\
\hline United Kingdom & 7.44 & 1.90 & 14 & 4.60 & 2.32 & 15 & 4.02 & 2.33 & 20 & 4.95 & 2.36 & 18 & 5.51 & 2.14 & 14 & 5.41 & 2.37 & 16 \\
\hline Greece & 6.62 & 2.18 & 22 & 3.51 & 2.33 & 23 & 4.29 & 2.48 & 17 & 6.01 & 2.45 & 8 & 4.77 & 2.41 & 23 & 4.36 & 2.64 & 23 \\
\hline Hungary & 6.22 & 2.45 & 27 & 2.99 & 2.14 & 27 & 3.20 & 2.57 & 27 & 3.90 & 2.44 & 28 & 4.71 & 2.36 & 24 & 3.56 & 2.40 & 27 \\
\hline Ireland & 7.91 & 1.75 & 6 & 5.60 & 2.44 & 7 & 5.20 & 2.35 & 7 & 5.41 & 2.37 & 14 & 6.68 & 2.30 & 4 & 4.04 & 2.64 & 24 \\
\hline Israel & 7.33 & 2.12 & 15 & 3.30 & 2.50 & 26 & 3.61 & 2.53 & 24 & 4.96 & 2.66 & 17 & 4.35 & 2.62 & 27 & 6.22 & 2.43 & 7 \\
\hline Iceland & 8.47 & 1.39 & 1 & 6.27 & 2.19 & 5 & 5.04 & 2.34 & 8 & 5.86 & 2.34 & 11 & 6.85 & 1.90 & 3 & 6.57 & 2.10 & 5 \\
\hline Italy & 6.46 & 2.09 & 26 & 4.12 & 1.97 & 19 & 3.91 & 2.27 & 23 & 4.93 & 2.24 & 19 & 5.01 & 2.00 & 21 & 4.67 & 2.19 & 19 \\
\hline Luxembourg & 7.83 & 1.91 & 8 & 6.55 & 2.06 & 2 & 6.27 & 2.08 & 1 & 6.73 & 2.19 & 2 & 5.37 & 2.50 & 16 & 7.07 & 2.30 & 2 \\
\hline Netherlands & 7.74 & 1.41 & 9 & 5.26 & 1.91 & 9 & 4.65 & 2.08 & 12 & 5.88 & 1.88 & 9 & 5.74 & 1.76 & 11 & 5.74 & 1.95 & 13 \\
\hline Norway & 7.92 & 1.54 & 5 & 6.47 & 2.20 & 3 & 4.64 & 2.03 & 13 & 6.40 & 1.99 & 6 & 6.31 & 1.82 & 6 & 5.75 & 2.08 & 12 \\
\hline Poland & 6.79 & 2.20 & 20 & 3.56 & 2.15 & 22 & 2.99 & 2.21 & 29 & 4.22 & 2.30 & 25 & 5.20 & 2.28 & 18 & 3.65 & 2.43 & 26 \\
\hline Portugal & 6.52 & 1.93 & 24 & 2.89 & 1.89 & 29 & 3.18 & 2.18 & 28 & 4.02 & 2.16 & 27 & 3.95 & 1.98 & 29 & 3.72 & 2.18 & 25 \\
\hline Russia & 5.97 & 2.25 & 28 & 3.51 & 2.24 & 24 & 4.68 & 2.54 & 11 & 3.72 & 2.44 & 29 & 4.38 & 2.40 & 25 & 3.43 & 2.34 & 28 \\
\hline Sweden & 7.86 & 1.59 & 7 & 5.28 & 2.11 & 8 & 4.99 & 2.16 & 9 & 6.21 & 2.15 & 7 & 5.53 & 2.09 & 13 & 5.55 & 2.23 & 15 \\
\hline Slovenia & 7.14 & 1.99 & 17 & 4.46 & 2.25 & 17 & 4.40 & 2.38 & 15 & 4.57 & 2.25 & 23 & 5.33 & 2.28 & 17 & 4.91 & 2.44 & 18 \\
\hline Slovakia & 6.48 & 2.03 & 25 & 4.26 & 2.33 & 18 & 4.35 & 2.45 & 16 & 4.53 & 2.35 & 24 & 5.47 & 2.28 & 15 & 4.40 & 2.58 & 22 \\
\hline Turkey & 6.66 & 2.58 & 21 & 4.83 & 3.21 & 13 & 5.92 & 3.31 & 4 & 4.98 & 3.08 & 16 & 5.16 & 3.31 & 20 & 5.63 & 3.30 & 14 \\
\hline Ukraine & 5.45 & 2.40 & 29 & 2.98 & 2.05 & 28 & 3.97 & 2.70 & 22 & 4.04 & 2.74 & 26 & 4.02 & 2.25 & 28 & 2.68 & 2.07 & 30 \\
\hline
\end{tabular}

Source: European Social Survey 2002, 2004, 2006 and 2008. The column labelled as rank provide the position occupied by a country in the ranking according to the mean value of the specific satisfaction domain. 
Table 3: Description of the decentralization variables

\begin{tabular}{|c|c|c|}
\hline \multirow{4}{*}{$\begin{array}{l}\text { Self Rule (SR) } \\
=\mathbf{I D}+\mathbf{P S}+\mathbf{F A}+\mathbf{R P} \\
\text { The authority exercised by a regional } \\
\text { government over those who live in } \\
\text { the region }\end{array}$} & $\begin{array}{l}\text { Institutional depth (ID) } \\
\text { Extent to which a regional } \\
\text { government is autonomous rather } \\
\text { than deconcentrated. }\end{array}$ & $\begin{array}{l}\text { 0: no functioning general-purpose administration at the regional level } \\
\text { 1: deconcentrated, general-purpose, administration } \\
\text { 2: non-deconcentrated, general-purpose, administration subject to central government veto } \\
\text { 3: non-deconcentrated, general-purpose, administration not subject to central government veto }\end{array}$ \\
\hline & $\begin{array}{l}\text { Policy Scope (PS) } \\
\text { Range of policies for which a } \\
\text { regional government is responsible }\end{array}$ & $\begin{array}{l}\text { 0: no authoritative competencies over economic policy, cultural-educational policy, welfare state policy } \\
\text { 1: authoritative competencies in one area: economic policy, cultural-educational policy, welfare state policy } \\
\text { 2: authoritative competencies in at least two areas: economic policy, cultural-educational policy, welfare } \\
\text { state policy } \\
\text { 3: authoritative competencies in at least two areas above, and in at least two of the following: residual } \\
\text { powers, police, authority over own institutional set-up, local government } \\
\text { 4: regional government meets the criteria for 3, and has authority over immigration or citizenship }\end{array}$ \\
\hline & $\begin{array}{l}\text { Fiscal Autonomy (FA) } \\
\text { Extent to which a regional } \\
\text { government can independently tax } \\
\text { its population }\end{array}$ & $\begin{array}{l}\text { 0: the central government sets base and rate of all regional taxes } \\
\text { 1: the regional government sets the rate of minor taxes } \\
\text { 2: the regional government sets base and rate of minor taxes } \\
\text { 3: the regional government sets the rate of at least one major tax: personal income, corporate, value added or } \\
\text { sales tax } \\
\text { 4: the regional government sets base and rate of at least one major tax: personal income, corporate, value } \\
\text { added or sales tax }\end{array}$ \\
\hline & $\begin{array}{l}\text { Representation (RP) } \\
\text { Extent to which a region is } \\
\text { endowed with an independent } \\
\text { legislature and executive: }\end{array}$ & $\begin{array}{l}\text { 0: no regional assembly } \\
\text { 1: an indirectly elected regional assembly } \\
\text { 2: a directly elected assembly } \\
\text { 3: the regional executive is appointed by central government } \\
\text { 4: dual executives appointed by central government and the regional assembly } \\
\text { 5: the regional executive is appointed by a regional assembly or directly elected }\end{array}$ \\
\hline \multirow{4}{*}{$\begin{array}{l}\text { Law Making (LM) } \\
=\text { LMA+LMB+LMC+LMD } \\
\text { Extent to which regional } \\
\text { representatives co-determine national } \\
\text { legislation, }\end{array}$} & Law Making A (LMA) & $\begin{array}{l}\text { 0: regional governments do not designate representatives in the legislature } \\
0.5 \text { : regional governments designate representatives in the legislature }\end{array}$ \\
\hline & Law Making B (LMB) & $\begin{array}{l}\text { 0: regional governments do not designate representatives in the legislature } \\
0.5 \text { : regional governments designate representatives in the legislature }\end{array}$ \\
\hline & Law Making C (LMC) & $\begin{array}{l}0 \text { : regions do not have majority representation in the legislature } \\
0.5 \text { : regions have majority representation in the legislature }\end{array}$ \\
\hline & Law Making D (LMD) & $\begin{array}{l}0: \text { the legislature with regional representation has extensive legislative authority } \\
0.5 \text { : the legislature with regional representation does not have extensive legislative authority }\end{array}$ \\
\hline
\end{tabular}


Table 3 (continuation)

\begin{tabular}{|c|c|c|}
\hline \multirow{3}{*}{$\begin{array}{l}\text { Shared Rule (SHR) } \\
=\mathbf{L M}+\mathbf{E C}+\mathbf{F C}+\mathbf{C R} \\
\\
\text { The authority exercised by a regional } \\
\text { government or its representatives in } \\
\text { the country as a whole. }\end{array}$} & $\begin{array}{l}\text { Executive Control (EC) } \\
\text { Extent to which a regional government } \\
\text { co-determines national policy in } \\
\text { intergovernmental meetings }\end{array}$ & $\begin{array}{l}\text { 0: no routine meetings between central and regional governments to negotiate policy } \\
\text { 1: routine meetings between central and regional governments without legally binding authority } \\
\text { 2: routine meetings between central and regional governments with authority to reach legally binding } \\
\text { decisions }\end{array}$ \\
\hline & $\begin{array}{l}\text { Fiscal Control (FC) } \\
\text { Extent to which regional } \\
\text { representatives co-determine the } \\
\text { distribution of national tax revenues }\end{array}$ & $\begin{array}{l}\text { 0: regional governments or their representatives in the legislature are not consulted over the distribution of } \\
\text { tax revenues } \\
\text { 1: regional governments or their representatives in the legislature negotiate over the distribution of tax } \\
\text { revenues, but do not have a veto } \\
\text { 2: regional governments or their representatives in the legislature have a veto over the distribution of tax } \\
\text { revenues }\end{array}$ \\
\hline & $\begin{array}{l}\text { Constitutional Reform }(\mathbf{C R}) \\
\text { Extent to which regional } \\
\text { representatives co-determine } \\
\text { constitutional change: }\end{array}$ & $\begin{array}{l}\text { 0: the central government and/or national electorate can unilaterally change the constitution } \\
\text { 1: a legislature based on the principle of regional representation must approve constitutional change; or } \\
\text { constitutional change requires a referendum based on the principle of equal } \\
\text { regional representation } \\
\text { 2: regional governments are a directly represented majority in a legislature which can do one or more of the } \\
\text { following: postpone constitutional reform, introduce amendments, raise the decision hurdle in the other } \\
\text { chamber, require a second vote in the other chamber, require a popular referendum } \\
\text { 3: a majority of regional governments can veto constitutional change }\end{array}$ \\
\hline Regional Authority Index (RAI) & $\mathbf{R A I}=\mathbf{S H R}+\mathbf{S R}$ & \\
\hline \multirow[t]{5}{*}{ Fiscal decentralization } & $\begin{array}{l}\text { Subnational Government } \\
\text { Expenditure (SNGE) }\end{array}$ & $\begin{array}{l}\text { Indicator: Subcentral Expenditure/General Expenditure } \\
\text { Definition Total Expenditure: (State Government + Local Government)/(Central Government-Social } \\
\text { Security + State Government + Local Government) } \\
\end{array}$ \\
\hline & $\begin{array}{l}\text { Subnational Current Expenditure } \\
\text { (SNCE) }\end{array}$ & $\begin{array}{l}\text { Indicator: Subcentral Current Expenditure/General Current Expenditure } \\
\text { Definition Current Expenditure: (State Government + Local Government)/(Central Government- } \\
\qquad \text { Social Security + State Government + Local Government) }\end{array}$ \\
\hline & $\begin{array}{l}\text { Subnational Capital Expenditure } \\
\text { (SNCAE) }\end{array}$ & $\begin{array}{l}\text { Indicator: Subcentral Capital Expenditure/General Capital Expenditure } \\
\text { Definition Capital Expenditure: (State Government + Local Government)/(Central Government-Social } \\
\qquad \text { Security + State Government + Local Government) }\end{array}$ \\
\hline & Subnational Revenue (SNR) & $\begin{array}{l}\text { Indicator: Subcentral Revenue \& Grants/General Revenue \& Grants } \\
\text { Definition Revenue \& Grants: (State Government + Local Government)/(Central Government - Social } \\
\text { Security + State Government + Local Government) }\end{array}$ \\
\hline & Subnational Tax Revenue (SNTR) & $\begin{array}{l}\text { Indicator: Subcentral Tax Revenue/General Tax Revenue } \\
\text { Definition Tax Revenue: (State Government + Local Government)/(Central Government - Social Security + } \\
\text { State Government + Local Government)] }\end{array}$ \\
\hline
\end{tabular}


Table 4: Time averaged decentralization indexes by country

\begin{tabular}{|c|c|c|c|c|c|c|c|c|c|c|}
\hline & \multicolumn{2}{|c|}{$\begin{array}{c}\text { Regional Authority } \\
\text { Index (RAI) }\end{array}$} & \multicolumn{2}{|c|}{ Self Rule } & \multicolumn{2}{|c|}{ Law Making } & \multicolumn{2}{|c|}{ Shared Rule } & \multicolumn{2}{|c|}{$\begin{array}{c}\text { Subnational Fiscal } \\
\text { Decentralization }\end{array}$} \\
\hline & Score & rank & Score & rank & Score & rank & Score & rank & Score & rank \\
\hline Austria & 18.00 & 6 & 12.00 & 7 & 1.00 & 7 & 6.00 & 4 & 0.42 & 8 \\
\hline Belgium & 28.34 & 2 & 21.08 & 1 & 1.95 & 3 & 7.26 & 2 & 0.47 & 5 \\
\hline Bulgaria & 1.00 & 23 & 1.00 & 23 & 0.00 & 12 & 0.00 & 13 & 0.26 & 17 \\
\hline Switzerland & 19.50 & 4 & 15.00 & 6 & 1.50 & 4 & 4.50 & 6 & 0.57 & 1 \\
\hline Cyprus & 0.00 & 24 & 0.00 & 23 & 0.00 & 12 & 0.00 & 13 & & \\
\hline Czech Republic & 3.07 & 22 & 3.07 & 22 & 0.00 & 12 & 0.00 & 13 & & \\
\hline Germany & 29.35 & 1 & 20.35 & 2 & 2.00 & 1 & 9.00 & 1 & 0.56 & 2 \\
\hline Denmark & 10.19 & 10 & 10.08 & 9 & 0.02 & 10 & 0.11 & 11 & 0.52 & 3 \\
\hline Estonia & 0.00 & 24 & 0.00 & 23 & 0.00 & 12 & 0.00 & 13 & & \\
\hline Spain & 22.02 & 3 & 19.00 & 3 & 1.26 & 6 & 3.02 & 7 & 0.46 & 6 \\
\hline Finland & 7.10 & 16 & 7.07 & 16 & 0.00 & 11 & 0.03 & 12 & 0.43 & 7 \\
\hline France & 16.00 & 8 & 16.00 & 5 & 0.00 & 12 & 0.00 & 13 & 0.29 & 14 \\
\hline United Kingdom & 8.70 & 15 & 8.33 & 14 & 0.07 & 8 & 0.37 & 9 & 0.27 & 15 \\
\hline Hungary & 9.67 & 13 & 9.67 & 12 & 0.00 & 12 & 0.00 & 13 & 0.33 & 13 \\
\hline Ireland & 5.76 & 18 & 5.76 & 18 & 0.00 & 12 & 0.00 & 13 & 0.35 & 11 \\
\hline Israel & & & & & & & & & 0.20 & 21 \\
\hline Iceland & 0.00 & 24 & 0.00 & 23 & 0.00 & 12 & 0.00 & 13 & 0.26 & 18 \\
\hline Italy & 19.36 & 5 & 17.93 & 4 & 0.00 & 12 & 1.43 & 8 & 0.34 & 12 \\
\hline Luxembourg & 0.00 & 24 & 0.00 & 23 & 0.00 & 12 & 0.00 & 13 & 0.21 & 20 \\
\hline Netherlands & 14.46 & 9 & 7.96 & 15 & 1.50 & 4 & 6.50 & 3 & 0.38 & 10 \\
\hline Norway & 10.00 & 11 & 10.00 & 10 & 0.00 & 12 & 0.00 & 13 & 0.39 & 9 \\
\hline Poland & 6.08 & 17 & 6.08 & 17 & 0.00 & 12 & 0.00 & 13 & 0.26 & 16 \\
\hline Portugal & 3.56 & 20 & 3.40 & 20 & 0.02 & 9 & 0.16 & 10 & 0.21 & 19 \\
\hline Russia & 17.76 & 7 & 11.76 & 8 & 2.00 & 1 & 6.00 & 4 & & \\
\hline Sweden & 10.00 & 11 & 10.00 & 11 & 0.00 & 12 & 0.00 & 13 & 0.51 & 4 \\
\hline Slovenia & 0.00 & 24 & 0.00 & 23 & 0.00 & 12 & 0.00 & 13 & & \\
\hline Slovakia & 3.40 & 21 & 3.40 & 21 & 0.00 & 12 & 0.00 & 13 & & \\
\hline Turkey & 5.00 & 19 & 5.00 & 19 & 0.00 & 12 & 0.00 & 13 & & \\
\hline
\end{tabular}

Note: The column labelled as Subnational Fiscal Decentralization is the average of the five specific fiscal decentralization indexes 
Table 5: Description of individual self-perceived indicators used as covariates in equation (3)

\begin{tabular}{|c|c|}
\hline Variable & Description \\
\hline Citizenship & $\begin{array}{l}\text { Are you a citizen of [country]? } \\
1 . \text { Yes / } 2 \text {. No }\end{array}$ \\
\hline Self-reported health & $\begin{array}{l}\text { How is your health in general? Would you say it is } \ldots \\
1 \text {. Very good } / 2 \text {. Good } / 3 \text {. Fair } / 4 \text {. Bad } / 5 \text {. Very bad }\end{array}$ \\
\hline left-right political position & $\begin{array}{l}\text { In politics people sometimes talk of "left" and "right". Using this card, where would you place yourself on this scale, where } 0 \\
\text { means the left and } 10 \text { means the right? } \\
0 . \text { Left / } 1 / 2 / \ldots / 10 \text { Right }\end{array}$ \\
\hline Feeling about income & $\begin{array}{l}\text { Which of the descriptions on this card comes closest to how you feel about your household's income nowadays? } \\
1 \text {. Living comfortably on present income / } 2 \text {. Coping on present income / 3. Finding it difficult on present income / } 4 \text {. Finding } \\
\text { it very difficult on present income }\end{array}$ \\
\hline
\end{tabular}


Table 6: Time-average (2002, 2004, 2006 and 2008) by country of the covariates in equation (3)

\begin{tabular}{|c|c|c|c|c|c|c|c|c|c|c|c|c|c|}
\hline & Age & $\begin{array}{c}\text { Self- } \\
\text { reported } \\
\text { Health }\end{array}$ & $\begin{array}{c}\text { Religious } \\
\text { level }\end{array}$ & $\begin{array}{c}\text { Left-right } \\
\text { political }\end{array}$ & Trust & $\begin{array}{c}\text { Feeling } \\
\text { about } \\
\text { income }\end{array}$ & $\begin{array}{c}\text { Household } \\
\text { size }\end{array}$ & Married & $\begin{array}{c}\text { Never } \\
\text { married }\end{array}$ & $\begin{array}{c}\text { Primary } \\
\text { and lower } \\
\text { education }\end{array}$ & $\begin{array}{c}\text { Post- } \\
\text { secondary } \\
\text { and tertiary } \\
\text { education }\end{array}$ & Citizen & Women \\
\hline Austria & 45.12 & 1.96 & 5.10 & 4.61 & 5.32 & 1.86 & 2.75 & 0.49 & 0.33 & 0.27 & 0.13 & 0.96 & 0.46 \\
\hline Belgium & 45.63 & 2.04 & 4.86 & 4.89 & 5.07 & 1.86 & 2.92 & 0.56 & 0.27 & 0.16 & 0.35 & 0.95 & 0.49 \\
\hline Bulgaria & 51.12 & 2.48 & 4.28 & 4.67 & 3.64 & 3.08 & 2.86 & 0.61 & 0.17 & 0.09 & 0.21 & 1.00 & 0.42 \\
\hline Switzerland & 48.48 & 1.89 & 5.31 & 4.96 & 5.85 & 1.65 & 2.36 & 0.52 & 0.27 & 0.05 & 0.28 & 0.87 & 0.46 \\
\hline Cyprus & 45.60 & 1.82 & 6.79 & 5.14 & 4.48 & 2.10 & 3.05 & 0.65 & 0.23 & 0.19 & 0.32 & 0.97 & 0.49 \\
\hline Czech Republic & 49.36 & 2.44 & 2.87 & 5.40 & 4.44 & 2.44 & 2.52 & 0.53 & 0.18 & 0.01 & 0.11 & 0.99 & 0.47 \\
\hline Germany & 47.77 & 2.35 & 3.91 & 4.51 & 5.14 & 1.94 & 2.55 & 0.55 & 0.27 & 0.02 & 0.33 & 0.96 & 0.50 \\
\hline Denmark & 48.07 & 1.90 & 4.27 & 5.43 & 6.78 & 1.41 & 2.56 & 0.57 & 0.28 & 0.02 & 0.38 & 0.98 & 0.49 \\
\hline Estonia & 47.48 & 2.61 & 3.59 & 5.24 & 5.21 & 2.37 & 2.79 & 0.44 & 0.32 & 0.06 & 0.35 & 0.81 & 0.42 \\
\hline Spain & 46.63 & 2.30 & 4.50 & 4.48 & 4.87 & 1.93 & 3.06 & 0.58 & 0.29 & 0.37 & 0.19 & 0.94 & 0.48 \\
\hline Finland & 47.32 & 2.19 & 5.35 & 5.70 & 6.36 & 1.93 & 2.51 & 0.50 & 0.32 & 0.19 & 0.29 & 0.99 & 0.48 \\
\hline France & 48.30 & 2.27 & 3.72 & 4.78 & 4.90 & 1.87 & 2.55 & 0.51 & 0.29 & 0.22 & 0.40 & 0.97 & 0.46 \\
\hline United Kingdom & 48.82 & 2.08 & 4.22 & 5.06 & 5.49 & 1.81 & 2.38 & 0.48 & 0.26 & 0.01 & 0.39 & 0.97 & 0.46 \\
\hline Greece & 49.84 & 1.96 & 7.50 & 5.67 & 3.53 & 2.57 & 2.75 & 0.62 & 0.22 & 0.40 & 0.16 & 0.95 & 0.44 \\
\hline Hungary & 47.86 & 2.65 & 4.36 & 5.22 & 4.33 & 2.53 & 2.98 & 0.53 & 0.23 & 0.32 & 0.15 & 1.00 & 0.45 \\
\hline Ireland & 46.90 & 1.78 & 5.91 & 5.34 & 5.96 & 1.73 & 3.36 & 0.56 & 0.32 & 0.23 & 0.30 & 0.97 & 0.45 \\
\hline Israel & 43.60 & 2.02 & 4.77 & 5.69 & 5.00 & 2.29 & 3.75 & 0.59 & 0.24 & 0.12 & 0.43 & 0.99 & 0.46 \\
\hline Iceland & 44.50 & 1.83 & 6.06 & 5.09 & 6.50 & 1.56 & 3.16 & 0.51 & 0.35 & 0.07 & 0.57 & 1.00 & 0.48 \\
\hline Italy & 46.93 & 2.27 & 6.08 & 4.79 & 4.41 & 1.85 & 3.14 & 0.60 & 0.29 & 0.23 & 0.09 & 1.00 & 0.45 \\
\hline Luxembourg & 43.38 & 2.16 & 4.29 & 5.08 & 5.14 & 1.60 & 3.16 & 0.55 & 0.32 & 0.31 & 0.20 & 0.69 & 0.50 \\
\hline Netherlands & 48.86 & 2.17 & 5.02 & 5.21 & 5.79 & 1.65 & 2.49 & 0.54 & 0.26 & 0.11 & 0.31 & 0.98 & 0.44 \\
\hline Norway & 45.68 & 1.98 & 3.93 & 5.24 & 6.55 & 1.55 & 2.67 & 0.52 & 0.32 & 0.01 & 0.41 & 0.96 & 0.52 \\
\hline Poland & 43.32 & 2.43 & 6.49 & 5.49 & 3.97 & 2.36 & 3.59 & 0.57 & 0.29 & 0.22 & 0.18 & 1.00 & 0.48 \\
\hline Portugal & 50.59 & 2.62 & 5.69 & 4.91 & 4.22 & 2.47 & 2.64 & 0.57 & 0.22 & 0.59 & 0.11 & 0.97 & 0.40 \\
\hline Russia & 46.64 & 2.86 & 4.35 & 5.28 & 4.22 & 2.82 & 2.51 & 0.46 & 0.22 & 0.08 & 0.55 & 1.00 & 0.40 \\
\hline Sweden & 46.92 & 1.99 & 3.56 & 5.11 & 6.27 & 1.54 & 2.58 & 0.45 & 0.38 & 0.21 & 0.32 & 0.97 & 0.50 \\
\hline Slovenia & 45.67 & 2.44 & 4.78 & 4.78 & 4.47 & 1.76 & 3.42 & 0.57 & 0.28 & 0.29 & 0.18 & 1.00 & 0.46 \\
\hline Slovakia & 45.51 & 2.40 & 5.93 & 4.87 & 4.22 & 2.46 & 3.32 & 0.57 & 0.24 & 0.02 & 0.15 & 1.00 & 0.45 \\
\hline Turkey & 39.19 & 2.34 & 7.06 & 6.32 & 3.39 & 2.46 & 4.11 & 0.66 & 0.24 & 0.62 & 0.07 & 1.00 & 0.45 \\
\hline Ukraine & 49.86 & 3.04 & 5.00 & 5.55 & 4.28 & 3.09 & 2.72 & 0.53 & 0.16 & 0.13 & 0.54 & 0.99 & 0.37 \\
\hline
\end{tabular}


Table 7: Linear random-effects estimates of equation (3). Random-effects and clustered standard errors are at year-country level.

\begin{tabular}{|c|c|c|c|c|c|c|c|c|c|c|c|c|}
\hline & \multicolumn{2}{|c|}{ Happiness } & \multicolumn{2}{|c|}{$\begin{array}{l}\text { Satisfaction with } \\
\text { economic situation }\end{array}$} & \multicolumn{2}{|c|}{$\begin{array}{l}\text { Satisfaction with } \\
\text { Government }\end{array}$} & \multicolumn{2}{|c|}{$\begin{array}{l}\text { Satisfaction with } \\
\text { democracy }\end{array}$} & \multicolumn{2}{|c|}{$\begin{array}{r}\text { Satisfaction with } \\
\text { education system }\end{array}$} & \multicolumn{2}{|c|}{$\begin{array}{l}\text { Satisfaction with } \\
\text { health system }\end{array}$} \\
\hline & Coef. & $t$-stat & Coef. & $\overline{t \text {-stat }}$ & Coef. & $t$-stat & Coef. & $t$-stat & Coef. & $t$-stat & Coef. & $\overline{t \text {-stat }}$ \\
\hline Constant & 6.7194 & $84.78^{* * *}$ & 3.9133 & $22.87^{* * * *}$ & 3.0742 & $13.84^{* * *}$ & 3.8131 & $24.84^{* * *}$ & 4.6142 & $29.28^{* * *}$ & 3.8510 & $18.93^{* * *}$ \\
\hline \multicolumn{13}{|l|}{ Individual variables } \\
\hline Age & -0.0330 & $-14.42^{* * *}$ & -0.0231 & $-7.18^{* * *}$ & -0.0246 & $-7.93^{* * *}$ & -0.0238 & $-8.31^{* * * *}$ & -0.0212 & $-5.51^{* * *}$ & -0.0405 & $-11.60^{* * *}$ \\
\hline Age Squared & 0.0003 & $14.79^{* * *}$ & 0.0002 & $7.04^{* * *}$ & 0.0003 & $9.61^{* * *}$ & 0.0002 & $8.47^{* * *}$ & 0.0002 & $4.63^{* * *}$ & 0.0005 & $12.44^{* * *}$ \\
\hline Woman & 0.0719 & $6.47^{* * *}$ & -0.2403 & $-8.91^{* * *}$ & -0.1267 & $-5.16^{* * *}$ & -0.1666 & $-9.28^{* * * *}$ & -0.0787 & $-4.23^{* * *}$ & -0.2681 & $-10.62^{* * *}$ \\
\hline \multicolumn{13}{|l|}{$\begin{array}{l}\text { Education } \\
\text { (Base: Lower primary) }\end{array}$} \\
\hline Primary & 0.1725 & $4.93^{* * *}$ & -0.2124 & $-4.12^{* * *}$ & -0.1096 & $-2.68^{* * *}$ & -0.1572 & $-3.57^{* * * *}$ & -0.0985 & $-2.38^{* * *}$ & -0.1152 & $-2.40^{* * *}$ \\
\hline Lower secondary & 0.1959 & $4.77^{* * *}$ & -0.3255 & $-4.92^{* * * *}$ & -0.1836 & $-3.19^{* * *}$ & -0.2594 & $-4.67^{* * *}$ & -0.3107 & $-5.29^{* * *}$ & -0.2541 & $-4.29^{* * *}$ \\
\hline Upper Secondary & 0.2439 & $6.02^{* * *}$ & -0.2788 & $-4.44^{* * * *}$ & -0.1716 & $-3.06^{* * *}$ & -0.1566 & $-2.78^{* * *}$ & -0.4124 & $-6.31^{* * *}$ & -0.3740 & $-5.73^{* * *}$ \\
\hline Post-secondary, non-tertiary & 0.2555 & $5.96^{* * *}$ & -0.2191 & $-3.17^{* * *}$ & -0.1328 & $-2.20^{* *}$ & -0.0989 & -1.46 & -0.5051 & $-6.89^{* * *}$ & -0.4519 & $-5.90^{* * *}$ \\
\hline First stage of tertiary & 0.2521 & $6.23^{* * *}$ & -0.1638 & $-2.43^{* * *}$ & -0.1353 & $-2.38^{* * *}$ & 0.0384 & 0.61 & -0.5836 & $-8.17^{* * *}$ & -0.3559 & $-4.68^{* * *}$ \\
\hline Second stage of tertiary & 0.2668 & $5.78^{* * *}$ & -0.1049 & -1.30 & -0.1742 & $-3.00^{* * *}$ & 0.0937 & $1.66^{*}$ & -0.5762 & $-8.08^{* * *}$ & -0.2670 & $-3.04^{* * *}$ \\
\hline Citizen & -0.1502 & $-6.10^{* * *}$ & 0.4430 & $5.18^{* * *}$ & 0.4900 & $5.19^{* * *}$ & 0.2923 & $3.50^{* * *}$ & 0.3235 & $2.99^{* * *}$ & 0.4652 & $6.29^{* * *}$ \\
\hline Self-reported health & -0.3956 & $-32.35^{* * *}$ & -0.1645 & $-16.78^{* * *}$ & -0.1164 & $-11.28^{* * *}$ & -0.1461 & $-14.23^{* * *}$ & -0.1064 & $-11.08^{* * *}$ & -0.1426 & $-13.78^{* * *}$ \\
\hline Level of religiosity & 0.0310 & $11.38^{* * *}$ & 0.0358 & $11.42^{* * *}$ & 0.0558 & $10.84^{* * *}$ & 0.0399 & $11.69^{* * *}$ & 0.0389 & $11.25^{* * *}$ & 0.0406 & $11.74^{* * *}$ \\
\hline Left-right political scale & 0.0226 & $5.56^{* * *}$ & 0.0556 & $4.27^{* * *}$ & 0.0615 & $1.88^{* * *}$ & 0.0561 & $3.82^{* * *}$ & 0.0195 & $2.03^{* *}$ & 0.0255 & $2.59^{* * *}$ \\
\hline Trust & 0.1510 & $34.46^{* * *}$ & 0.2349 & $39.05^{* * *}$ & 0.2264 & $29.20^{* * *}$ & 0.2544 & $35.07^{* * *}$ & 0.1985 & $39.96^{* * *}$ & 0.2166 & $31.78^{* * *}$ \\
\hline \multicolumn{13}{|l|}{$\begin{array}{l}\text { Marital status } \\
\text { (Base: Married) }\end{array}$} \\
\hline Separated & -0.6012 & $-12.88^{* * *}$ & -0.1587 & $-2.89^{* * *}$ & -0.1666 & $-2.75^{* * *}$ & -0.1462 & $-2.72^{* * * *}$ & -0.1252 & $-2.43^{* * *}$ & -0.0542 & -1.02 \\
\hline Divorced & -0.3909 & $-14.30^{* * *}$ & -0.1170 & $-5.72^{* * *}$ & -0.1557 & $-6.31^{* * *}$ & -0.0934 & $-3.79^{* * * *}$ & -0.0785 & $-3.32^{* * *}$ & 0.0112 & 0.42 \\
\hline Widowed & -0.5257 & $-20.30^{* * *}$ & -0.0061 & -0.25 & 0.0068 & 0.29 & 0.0590 & $2.12^{* *}$ & -0.0057 & -0.26 & 0.0393 & 1.32 \\
\hline Never married & -0.3371 & $-18.95^{* * *}$ & -0.0484 & $-2.39^{* * *}$ & -0.0413 & $-1.98^{* *}$ & -0.0059 & -0.27 & -0.0905 & $-5.18^{* * *}$ & 0.0359 & 1.42 \\
\hline \multicolumn{13}{|l|}{$\begin{array}{l}\text { Feeling about present income } \\
\text { (Base: living comfortable) }\end{array}$} \\
\hline Coping & -0.1966 & $-13.59^{* * *}$ & -0.3943 & $-16.04^{* * *}$ & -0.2277 & $-10.60^{* * *}$ & -0.2336 & $-12.56^{* * *}$ & -0.0837 & $-3.63^{* * *}$ & -0.1577 & $-9.77^{* * *}$ \\
\hline Difficult & -0.6900 & $-22.14^{* * *}$ & -0.8420 & $-24.78^{* * *}$ & -0.4919 & $-16.34^{* * *}$ & -0.4996 & $-15.27^{* * *}$ & -0.2616 & $-6.98^{* * *}$ & -0.3317 & $-12.69^{* * *}$ \\
\hline Very difficult & -1.3557 & $-23.76^{* * *}$ & -1.2993 & $-25.16^{* * *}$ & -0.8232 & $-16.71^{* * *}$ & -0.8519 & $-17.93^{* * *}$ & -0.4395 & $-9.35^{* * *}$ & -0.5877 & $-14.14^{* * *}$ \\
\hline Household size & 0.0147 & $2.30^{* * *}$ & -0.0047 & -0.81 & -0.0013 & -0.21 & -0.0028 & -0.48 & 0.0027 & 0.43 & 0.0364 & $4.58^{* * *}$ \\
\hline
\end{tabular}

Significant at " 1 percent, " 5 percent and " 10 percent level. 


\begin{tabular}{|c|c|c|c|c|c|c|c|c|c|c|c|c|}
\hline & \multicolumn{2}{|c|}{ Happiness } & \multicolumn{2}{|c|}{$\begin{array}{r}\text { Satisfaction } \\
\text { economic situation }\end{array}$} & \multicolumn{2}{|c|}{$\begin{array}{l}\text { Satisfaction } \\
\text { government }\end{array}$} & \multicolumn{2}{|c|}{$\begin{array}{r}\text { Satisfaction } \\
\text { democracy }\end{array}$} & \multicolumn{2}{|c|}{$\begin{array}{r}\text { Satisfaction } \\
\text { education system }\end{array}$} & \multicolumn{2}{|c|}{$\begin{array}{r}\text { Satisfaction } \\
\text { health system }\end{array}$} \\
\hline & Coef. & $t$-stat & Coef. & $t$-stat & Coef. & $t$-stat & Coef. & $t$-stat & Coef. & $t$-stat & Coef. & $t$-stat \\
\hline \multicolumn{13}{|l|}{ Decentralization indexes } \\
\hline \multicolumn{13}{|l|}{ Political decentralization } \\
\hline Regional Authority Index $\mathrm{SR}+\mathrm{SHR}$ & 0.0103 & $2.94^{* * *}$ & -0.0063 & -0.61 & -0.0010 & -0.11 & 0.0176 & $2.34^{* * *}$ & 0.0001 & 0.01 & 0.0405 & $3.16^{* * *}$ \\
\hline Self-rule (SR) ID+PS+FA+RP & 0.0140 & $2.82^{* * *}$ & -0.0073 & -0.52 & -0.0024 & -0.20 & 0.0277 & $2.65^{* * *}$ & 0.0048 & 0.37 & 0.0549 & $3.36^{* * *}$ \\
\hline Law making $(\mathrm{LM}) \mathrm{A}+\mathrm{B}+\mathrm{C}+\mathrm{D}$ & 0.1099 & $2.73^{* * *}$ & -0.0433 & -0.38 & 0.0805 & 0.77 & 0.1114 & 1.20 & -0.0623 & -0.54 & 0.3932 & $2.53^{* * *}$ \\
\hline Shared rule (SHR) LM+EC+FC+CR & 0.0246 & $2.47^{* * *}$ & -0.0208 & -0.68 & 0.0029 & 0.10 & 0.0230 & 1.10 & -0.0229 & -0.75 & 0.0953 & $2.36^{* * *}$ \\
\hline $\mathrm{R}^{2}$ within & & 0.2115 & & 0.1249 & & 0.0834 & & 0.1046 & & 0.0540 & & 0.0739 \\
\hline $\mathrm{R}^{2}$ between & & 0.8787 & & 0.7201 & & 0.5084 & & 0.7029 & & 0.5530 & & 0.4624 \\
\hline $\mathrm{R}^{2}$ overall & & 0.2901 & & 0.2309 & & 0.1392 & & 0.1916 & & 0.1078 & & 0.1459 \\
\hline Fraction of variance due to $u_{c t}$ & & 0.0125 & & 0.1049 & & 0.0802 & & 0.0300 & & 0.0677 & & 0.0913 \\
\hline Sample size & & 110,739 & & 120,251 & & 118,591 & & 118,067 & & 115,323 & & 119,376 \\
\hline \multicolumn{13}{|l|}{ Fiscal decentralization } \\
\hline$\overline{\text { Sub-national Gov. Expenditure }}$ & 1.4038 & $5.39^{* * *}$ & 2.3390 & $6.28^{* * *}$ & 2.6617 & $6.97^{* * *}$ & 3.6609 & $3.34^{* * *}$ & 4.5025 & $4.12^{* * *}$ & 3.0969 & $3.76^{* * *}$ \\
\hline Sub-national Current Expenditure & 0.6418 & $3.65^{* * *}$ & 0.6563 & $2.73^{* * *}$ & 0.8512 & $3.39^{* * *}$ & 0.5970 & 0.98 & 1.1907 & $2.14^{* *}$ & 1.3257 & $2.68^{* * *}$ \\
\hline Sub-national Capital Expenditure & 1.3427 & $4.87^{* * *}$ & 2.2777 & $6.18^{* * *}$ & 2.5498 & $6.75^{* * *}$ & 3.9337 & $3.83^{* * *}$ & 4.6324 & $4.49^{* * *}$ & 2.8606 & $3.57^{* * *}$ \\
\hline Sub-national Revenue & 0.7451 & $4.18^{* * *}$ & 1.3601 & $5.58^{* * *}$ & 1.6017 & $6.56^{* * *}$ & 2.3636 & $3.68^{* * *}$ & 3.0387 & $5.04^{* * * *}$ & 1.4414 & $2.97^{* * *}$ \\
\hline Sub-national Tax Revenue & 0.5796 & $3.15^{* * *}$ & 1.0422 & $3.69^{* * *}$ & 1.5664 & $5.98^{* * *}$ & 1.2245 & 1.45 & 2.6368 & $3.14^{* * *}$ & 1.4706 & $2.17^{* *}$ \\
\hline $\mathrm{R}^{2}$ within & & 0.2099 & & 0.1198 & & 0.0833 & & 0.1038 & & 0.0511 & & 0.0745 \\
\hline $\mathrm{R}^{2}$ between & & 0.8377 & & 0.5743 & & 0.5348 & & 0.7297 & & 0.4932 & & 0.3726 \\
\hline $\mathrm{R}^{2}$ overall & & 0.2881 & & 0.2457 & & 0.1684 & & 0.2213 & & 0.132 & & 0.1297 \\
\hline Fraction of variance due to $u_{c t}$ & & 0.0076 & & 0.1167 & & 0.0720 & & 0.0230 & & 0.0881 & & 0.0839 \\
\hline Sample size & & 92,886 & & 101,845 & & 100,617 & & 100,194 & & 98,571 & & 101,409 \\
\hline
\end{tabular}

Significant at ${ }^{* * *} 1$ percent, $" 5$ percent and " 10 percent level. 
Table 9: Decentralization-SWB elasticities.

\begin{tabular}{|c|c|c|c|c|c|c|}
\hline & Happiness & $\begin{array}{c}\text { Economic } \\
\text { situation }\end{array}$ & Government & Democracy & $\begin{array}{r}\text { Education } \\
\text { system }\end{array}$ & $\begin{array}{l}\text { Health } \\
\text { system }\end{array}$ \\
\hline \multicolumn{7}{|l|}{ Aggregated } \\
\hline Regional Authority Index SR+SHR & 0.0234 & & & 0.0551 & & 0.1290 \\
\hline Self-rule (SR) ID+PS+FA+RP & 0.0263 & & & 0.0720 & & 0.1454 \\
\hline Law making $(\mathrm{LM}) \mathrm{A}+\mathrm{B}+\mathrm{C}+\mathrm{D}$ & 0.0101 & & & & & 0.0509 \\
\hline $\begin{array}{l}\text { Shared rule (SHR) } \mathrm{LM}+\mathrm{EC}+\mathrm{FC}+\mathrm{CR} \\
\text { Fiscal decentralization }\end{array}$ & 0.0093 & & & & & 0.0508 \\
\hline Sub-national Gov. Expenditure & 0.1369 & 0.2556 & 0.3931 & 0.3596 & 0.4770 & 0.6190 \\
\hline Sub-national Current Expenditure & 0.0565 & 0.1150 & 0.0995 & & 0.0702 & 0.1477 \\
\hline Sub-national Capital Expenditure & 0.0653 & 0.1203 & 0.1910 & 0.1720 & 0.2558 & 0.3179 \\
\hline Sub-national Revenue & 0.0365 & 0.0714 & 0.1150 & 0.1088 & 0.1549 & 0.2101 \\
\hline Sub-national Tax Revenue & 0.0222 & 0.0562 & 0.0687 & & 0.0626 & 0.1421 \\
\hline
\end{tabular}

Note: Only elasticities derived from significant coefficients in table 7 are reported. 